\section{Molecular Heterogeneity of the Chalcone Synthase Intron in Petunia}

\author{
R.J. Griesbach ${ }^{1}$ and R.M. Beck \\ Floral and Nursery Plant Research, U.S. NationalArboretum, U.S. Department \\ of Agriculture, Agricultural Research Service, Beltsville, MD 20705-2350
}

\section{J.R. Stehmann}

Departamento de Botânica, Universidada Federal de Minas Gerais, Av. Antônio Carlos, 6627, 31270-110, Belo-Horizonte, MG, Brazil

Additional index words. Petunia $\times$ hybrida, P. integrifolia, P. altiplana, molecular markers

\begin{abstract}
A method was developed to characterize the genetic heterogeneity of the chalcone synthase gene intron within the Petunia integrifolia (Hook.) Schinz \& Thell. species complex. The DNA from wild species collected from known locations was used to amplify the chalcone synthase gene intron through the polymerase chain reaction (PCR). The resulting PCR product was then characterized by $R s a 1$ restriction, revealing a degree of heterogeneity that could be used to characterize the species genetically. Of the four different species that were characterized, two could be placed in the same genetic grouping. This study shows that the variation in the intron of the $C h s A$ gene may be species-specific.
\end{abstract}

The genus Petunia was established by Jussieu (1803). The first monograph on this genus was written by Fries (1911), who separated the genus into two subgenera, Pseudonicotiana and Eupetunia. Species within the Pseudonicotiana subgenus had long and narrow corolla tubes, while the Eupetunia species had short, wide corolla tubes. The garden petunia, Petunia $\times$ hybrida Hort. Vilm., is a complex hybrid of $P$. integrifolia (Hook.) Schinz \& Thell. (Eupetunia) and P. axillaris Lindl. (Pseudonicotiana) that originated about 1825 (Sink, 1984). Fries recognized three distinct Eupetunia species ( $P$. violacea Lindl., $P$. inflata Fries, and P. occidentalis Fries). Petunia violacea had the largest flowers and pendant pedicels, while $P$. occidentalis had the smallest flowers and erect pedicels. Petunia inflata was intermediate between $P$. violacea and $P$. occidentalis. In addition, Fries recognized a diminutive subspecies of $P$. violacea ( $P$. violacea subsp. depauperata Fries) with very small flowers and leaves.

There has been considerable confusion as to the taxonomic relationships between these Eupetunia species. Schinz and Thellung (1915) discovered that the plant previously described by Hooker (1831) as Salpiglossis integrifolia Hooker was actually a Petunia species $(P$. integrifolia). Subsequently, Smith and Downs (1966) recognized that $P$. integrifolia and $P$. violacea were identical. Because the description of $P$. integrifolia predated that of $P$. violacea, $P$. integrifolia was the correct name for the species.

Wijsman (1982) studied multiple ecotypes of $P$. integrifolia and discovered that both

Received for publication 22 Sept. 1999. Accepted for publication 11 Jan. 2000. The cost of publishing this paper was defrayed in part by the payment of page charges Under postal regulations, this paper therefore must be hereby marked advertisement solely to indicate this fact. ${ }^{1}$ To whom reprint requests should be addressed. E-mail: griesbac@asrr.arsusda flower size and pedicel position were correlated with geographical distribution. The more western ecotypes of Brazil had smaller flowers and more erect pedicels. He concluded that $P$. integrifolia, $P$. inflata, and $P$. occidentalis were not distinct species, but were subspecies of a single, broadly defined species [i.e., $P$. integrifolia subsp.integrifolia (Fries) Wijsman, $P$. integrifolia subsp. inflata (Fries) Wijsman, and $P$. integrifolia subsp. occidentalis (Fries) Wijsman].

Not all taxonomists agree with Wijsman, and some have given ecotypes in the $P$. integrifolia complex independent species status: $P$. scheideana Smith \& Downs (Smith and Downs, 1964), P. littoralis Smith \& Downs (Smith and Downs, 1966), P. bonjardinensis Ando \& Hash. and P. altiplana Ando \& Hash. (Ando and Hashimoto, 1993), P. mantiqueirensis Ando \& Hash. (Ando and Hashimoto, 1994), P. guarapuavensis Ando \& Hash. (Ando and Hashimoto, 1995), P. interior Ando \& Hash. (Ando and Hashimoto, 1996), P. bajeensis Ando. \& Hash. and $P$. riograndensis Ando \& Hash. (Ando and Hashimoto, 1998), and P. occidentalis Tsuk. (Tsukamoto et al., 1998). Wijsman believes that these ecotypes should have been described as subspecies of $P$. integrifolia (personal communication).

Several molecular marker studies of Petunia have been made using species-specific repeated DNA (Shepherd et al., 1990), rDNA (Kabbaj et al., 1995; Zeboudj et al., 1994), and randomly amplified DNA (Cerny et al., 1996). However, in all of these studies, the species actually used is uncertain. For example, phylogenetic analysis using rDNA suggested that $P$. integrifolia was very distantly related to $P$. violacea (Kabbaj et al., 1995), but these are the same species! Furthermore, the complex taxonomy of Petunia has caused many cultivated species to be misidentified. For example, we have received from a botanical garden in Eu- rope seed of a Eupetunia x Pseudonicotiana hybrid that was distributed as $P$. violacea.

The purpose of this study was to characterize the genetic heterogeneity of the chalcone synthase gene intron within the $P$. integrifolia species complex. Wild Petunia species collected from known locations were used.

\section{Material and Methods}

Plant material. Two accessions, each from two different species, $P$. integrifolia ssp. depauperata '2' (Longwood Gardens 77320), P. integrifolia ssp. depauperata '3' (30³1'14'” south, 5327'09" west), $P$. altiplana '7' (29 $24^{\prime} 02^{\prime \prime}$ south, 50 $26^{\prime} 57^{\prime \prime}$ west) and $P$. altiplana ' 8 ' (28॰12'37' south, 49 47'17'" west), and a single accession of an unknown species $P$. sp. 'Torres' $\left(29^{\circ} 21^{\prime} 26^{\prime}\right.$ ' south, $49^{\circ} 44^{\prime} 06^{\prime \prime}$ west) were analyzed. All but the first were collected from the wild, and each was from a genetically distinct population. We also analyzed two cultivated Petunia hybrids, P. Xhybrida 'Magic White' (Pan American Seed, West Chicago, Ill.) and P. Xhybrida 'Prime Time Blue' (Goldsmith Seed, Gilroy, Calif.), from genetically distinct breeding programs. Potted plants were grown under standard greenhouse conditions in Beltsville, Md., and fertilized weekly with a solution of $20 \mathrm{~N}-$ 8.7P-16.6K fertilizer at $200 \mathrm{mg} \cdot \mathrm{L}^{-1}$ nitrogen.

DNA isolation. Plants were placed in the dark $24 \mathrm{~h}$ before DNA extraction in order to reduce their polysaccharide content. DNA was extracted by grinding young fully expanded leaves (100 mg fresh weight) in liquid nitrogen and isolated using the Nucleon PhytoPure Plant DNA Extraction Kit (Vector Laboratories, Burlingame, Calif.) as recommended by the manufacturer.

The DNA was further purified from polysaccharides by elution from DEAE-cellulose (Marechal-Drouard et al., 1995). The DEAE-cellulose $(1.5 \mathrm{~g})$ was resuspended in $20 \mathrm{~mL}$ of elution buffer $(2 \mathrm{M} \mathrm{NaCl}, 1 \mathrm{~mm}$ EDTA, and $10 \mathrm{~mm}$ TRIS, pH 7.5), washed several times in the same buffer, and then in wash buffer ( $400 \mathrm{~mm} \mathrm{NaCl}, 1 \mathrm{~mm}$ EDTA, and 10 mm TRIS, pH 7.5), and finally resuspended in $5 \mathrm{~mL}$ of wash buffer. The DNA pellets from four 100-mg extractions were combined, dissolved in $100 \mu \mathrm{L}$ of TE (100 mM TRIS, pH 8.0, and $1 \mathrm{~mm}$ EDTA), and thoroughly mixed with $100 \mu \mathrm{L}$ of DEAE-cellulose. The suspension was centrifuged at $3000 g_{\mathrm{n}}$ for $30 \mathrm{~s}$, the supernatant discarded, and DEAE-bound DNA washed several times with wash buffer. The DNA was released from the DEAE by suspension in $500 \mu \mathrm{L}$ of elution buffer. The eluted DNA was precipitated with an equal volume of isopropanol, washed with $70 \%$ ethanol, and resuspended in $50 \mu \mathrm{L}$ of TE.

$P C R$ amplification. The DNA sequences of the chalcone synthase genes $(C h s)$ from both $P$. ×hybrida 'V30' (Koes et al., 1989) and $P$. ×hybrida 'Roter Traum' (NiesbachKlösgen et al., 1987) have been reported. The sequence from $P$. ×hybrida 'Roter Traum' was selected for creating primers to amplify the $C h s$ intron. The forward primer sequence (5'-GAGAAATTCAAGCGNATGTG-3'), 
designated CHS-1, was selected from the region immediately before the intron. The reverse primer sequence (5'AACCCTGCTGGTACATCATG-3'), designated CHS-4, was selected from a transcribed region of the gene $312 \mathrm{bp}$ downstream from the intron. The sequences complementary to CHS-4 are very highly conserved between unrelated species in different genera (NiesbachKlösgen et al., 1987).

The PCR reactions were performed in a Perkin Elmer DNA Thermal Cycler Version 2.3 (Perkin-Elmer Corp., Norwalk, Conn.). The reaction mix $(100 \mu \mathrm{L})$ contained $1 \mu \mathrm{L}$ genomic DNA $\left(0.1 \mathrm{mg} \cdot \mathrm{mL}^{-1}\right), 1 \mu \mathrm{L}$ AmpiTaq Gold DNA polymerase (PE Applied Biosystems, San Jose, Calif.), $10 \mu \mathrm{L}$ of $10 \mathrm{X}$ buffer (500 mM KCl and $150 \mathrm{~mm}$ Tris, $\mathrm{pH} 8.0$ ), $8 \mu \mathrm{L}$ mixed dNTPs (each at $10 \mathrm{~mm}$ ), $25 \mu \mathrm{L} 10$ mM $\mathrm{MgCl}_{2}, 5 \mu \mathrm{L}$ of $20 \mu \mathrm{M}$ CHS- 1 primer, $5 \mu \mathrm{L}$ of $20 \mu \mathrm{M}$ CHS -4 primer, and $45 \mu \mathrm{L}$ of water. Each reaction mixture was overlaid with 25 $\mu \mathrm{L}$ of mineral oil and was preheated at $95{ }^{\circ} \mathrm{C}$ for $12 \mathrm{~min}$. Following a 2 -min incubation at 92 ${ }^{\circ} \mathrm{C}$, and 40 cycles of $92{ }^{\circ} \mathrm{C}(30 \mathrm{~s}), 60^{\circ} \mathrm{C}(2$ $\mathrm{min})$, and $72{ }^{\circ} \mathrm{C}(1 \mathrm{~min})$, the reaction was terminated with a $72{ }^{\circ} \mathrm{C} 10$-min incubation and held at $5{ }^{\circ} \mathrm{C}$.

Restriction analysis. Analysis of the published sequence of the Chs intron in $P$. Xhybrida 'V30' (Koes et al., 1989) revealed that only $R s a 1$ would digest the intron into several large fragments. The PCR products were then digested with Rsa I (New England BioLabs, Beverly, Mass.) at $37^{\circ} \mathrm{C}$ for $3 \mathrm{~h}$. The restriction mixture $(200 \mu \mathrm{L})$ consisted of $30 \mu \mathrm{L}$ PCR product, $150 \mu \mathrm{L}$ water, $20 \mu \mathrm{L} 10 \mathrm{X}$ buffer $(10$ $\mathrm{mm} \mathrm{MgCl}_{2}, 1 \mathrm{~mm}$ dithiothreitol, and $10 \mathrm{~mm}$ Tris, pH 7.0), and 10 units Rsa 1 .

The PCR products and restriction fragments were resolved by gel electrophoresis (50-V constant voltage) in 4\% Amplisize Agarose (Bio-Rad, Hercules, Calif.) in TAE. Gels were stained in $0.5 \mu \mathrm{g} \cdot \mathrm{mL}^{-1}$ ethidium bromide for $45 \mathrm{~min}$. The AlphaEase image analysis system (Alpha Innotech Corp., San Leandro, Calif.) was used to digitally record the resulting images and to determine molecular weights. From the published DNA sequence of the Chs intron in $P . \times$ hybrida 'V30' (Koes et al., 1989), fragments $<100 \mathrm{bp}$ were expected. However, the molecular weight of these small fragments could not be accurately determined and were not included in the analysis.

\section{Results and Discussion}

Chalcone synthase is the key enzyme of the anthocyanin biosynthethic pathway, and cDNAs of this gene have been isolated and sequenced from many species in several families. Comparison of the coding region of the Chs gene in these species revealed a $66 \%$ nucleotide similarity (Niesbach-Klösgen etal.,

Fig. 1. Sequence of the primers used to amplify the chalcone synthase gene intron and the complementary sequence found in the Chs genes of $P$. $\times$ hybrida 'V30'. The primers were not derived from the $P$. ×hybrida 'V30' sequence (Koes et al., 1989), but from the $P$. ×hybrida 'Roter Traum' sequence (Niesbach-Klösgen et al., 1987). The accession number of the Chs genes were: Chs A, X14591; Chs F, X14594; Chs J, X14597; Chs G, X14595; Chs D, X14593; and Chs B, X14592 (Koes et al., 1989).

\begin{tabular}{|c|c|c|c|c|c|c|c|c|c|c|c|c|c|c|c|c|c|c|c|c|}
\hline Forward Primer & G & A & G & A & A & A & $\mathrm{T}$ & $\mathrm{T}$ & $\mathrm{C}$ & A & A & G & $\mathrm{C}$ & G & $\mathrm{N}$ & A & $\mathrm{T}$ & G & $\mathrm{T}$ & G \\
\hline$\overline{C h s A}$ & - & - & - & - & - & - & - & - & $\mathrm{T}$ & - & - & - & - & - & $\mathrm{C}$ & - & - & - & - & - \\
\hline Chs F & - & - & - & - & - & $\mathrm{G}$ & - & - & $\mathrm{T}$ & - & - & - & - & - & $\mathrm{C}$ & - & - & - & - & - \\
\hline Chs $J$ & - & - & - & - & - & $\mathrm{G}$ & - & - & $\mathrm{T}$ & $\mathrm{C}$ & - & - & - & - & $\mathrm{C}$ & - & - & - & - & - \\
\hline Chs $G$ & - & - & - & - & - & G & - & - & $\mathrm{T}$ & - & - & A & - & A & $\mathrm{C}$ & - & - & - & - & - \\
\hline Chs D & - & - & - & - & - & G & - & - & $\mathrm{T}$ & - & - & A & - & - & $\mathrm{T}$ & - & - & $\mathrm{C}$ & - & - \\
\hline Chs B & - & - & A & - & - & G & - & - & $\mathrm{T}$ & - & G & A & - & - & $\mathrm{T}$ & - & - & $\mathrm{T}$ & - & - \\
\hline Reverse Primer & $\mathrm{C}$ & A & $\mathrm{T}$ & G & A & $\mathrm{T}$ & G & $\mathrm{T}$ & A & $\mathrm{C}$ & $\mathrm{C}$ & A & G & $\mathrm{C}$ & A & G & G & G & $\mathrm{T}$ & $\mathrm{T}$ \\
\hline$\overline{C h s A}$ & - & - & - & - & - & - & - & - & - & - & - & - & $\mathrm{A}$ & - & - & $\mathrm{A}$ & - & - & - & - \\
\hline Chs $J$ & - & - & - & - & - & - & - & - & - & - & - & - & A & - & - & A & - & - & - & - \\
\hline Chs F & - & - & - & - & - & - & - & - & - & - & - & - & A & - & $\mathrm{T}$ & A & - & - & - & - \\
\hline Chs $G$ & A & - & - & - & - & - & - & - & - & - & - & - & A & - & - & A & - & - & $\mathrm{G}$ & - \\
\hline Chs D & - & - & - & - & - & - & - & A & - & - & - & - & A & - & $\mathrm{T}$ & A & - & - & - & - \\
\hline Chs B & A & - & - & - & - & - & - & - & - & - & - & - & A & - & - & A & - & - & - & - \\
\hline
\end{tabular}

1987). In $P$. ×hybrida 'V30', chalcone synthase is part of a multigene family with eight complete (Chs A, B, D, F, G, H, J, and $L$ ) and four incomplete (Chs $C, E, I$, and $K$ ) copies of the $C h s$ gene per haploid genome (Koes et al., 1989). The Chs A gene is the only Chs gene transcribed to a significant extent in flower tissue. The $C h s A, B, D$, and $F$ genes are located on chromosome V, whereas the $C h s G$ and $L$ genes are located tightly linked together on chromosome II. Each complete Chs gene consists of two exons separated by an intron of variable size and sequence (Koes et al., 1989). The lengths of the introns in $C h s A, B, D, F, G$, $H, J$, and $L$ are, respectively, $1346,3776,694$, $563,2438,406,728$, and 123 bp. Homologous genes for each of the complete $C h s$ genes in $P$. $\times$ hybrida 'V30' have been found in species identified as $P$. axillaris, $P$. parodii Smith \& Downs, $P$. inflata, and $P$. violacea (Koes et al., 1987). The incomplete $C h s$ genes do not contain an intron.

Niesbach-Klösgen et al. (1987) did not report the number of $C h s$ genes in $P . \times$ hybrida 'Roter Traum' or the size of their introns. Only a single DNA sequence was published. From this sequence, primers were designed to amplify the intron plus an additional $312 \mathrm{bp}$ of the gene. Because of the small difference between the $C h s A, B, D, F, G$, and $J$ gene sequences from $P$. $\times$ hybrida 'V30', we expected the primers to amplify more than one of the Chs genes (Fig. 1). However, in all but two accessions a single PCR product was obtained (Table 1; Fig. 2).

The PCR products in $P$. $\times$ hybrida 'Prime Time Blue' and 'Magic White' were the same length (1275 bp) and did not match the length of any of the P. Xhybrida 'V30' Chs genes (Table 1). Rsa I digestion of these products resulted in three fragments $>100 \mathrm{bp}$ in length at 615,390 , and $280 \mathrm{bp}$. These fragments did not correspond in length to any of the published sequences of the Chs genes (Table 1). We are confident that our primers amplified the $C h s A$ gene because the sequence of the 234 nucleotides from the $3^{\prime}$ end of the PCR product differed from the reported $C h s A$ gene sequence by only a single nucleotide (data not shown).

The length of the PCR product (1275 bp) and $R s a I$ restriction fragments $(615,390$, and $280 \mathrm{bp}$ ) of $P$. $\times$ hybrida 'Prime Time Blue' and

Table 1. The lengths (bp) of the Rsa I restriction fragments of the PCR products containing the intron of chalcone synthase. Only fragments over $100 \mathrm{bp}$ are reported The PCR primers were not expected to amplify the intron in $C h s H$ or $L$. The first line is the length of the unrestricted PCR product. In $P$. altiplana '7' and ' 8 ', there were two unrestricted products. In P. altiplana 8 , the $1220 \mathrm{bp} \mathrm{PCR} \mathrm{product} \mathrm{produced} \mathrm{a} 825 \mathrm{bp}$ fragment, while the 1185 bp PCR product produced a 785 bp fragment. The specific Chs gene fragments were calculated from the sequences reported in the literature for $P$. ×hybrida 'V30' (Koes et al., 1989). The accession number of the Chs genes were: Chs A, X14591; Chs F, X14594; Chs J, X14597; Chs G, X14595; Chs D, X14593; and Chs B, X14592.

\begin{tabular}{|c|c|c|c|c|c|c|c|c|c|c|}
\hline & & & & & Species & & & & & \\
\hline hybrida & integrifolia & altiplana 7 & altiplana 8 & 'Torres' & Chs A & Chs B & Chs D & Chs F & Chs $G$ & Chs J \\
\hline 615 & 825 & 825 & $825 / 785$ & 710 & 718 & 1316 & 677 & 794 & 1249 & 357 \\
\hline 280 & & & & 190 & 273 & 528 & 154 & & 343 & 173 \\
\hline & & & & & 116 & 351 & & & 273 & 100 \\
\hline & & & & & 108 & 291 & & & 101 & \\
\hline & & & & & & 208 & & & & \\
\hline & & & & & & 104 & & & & \\
\hline
\end{tabular}



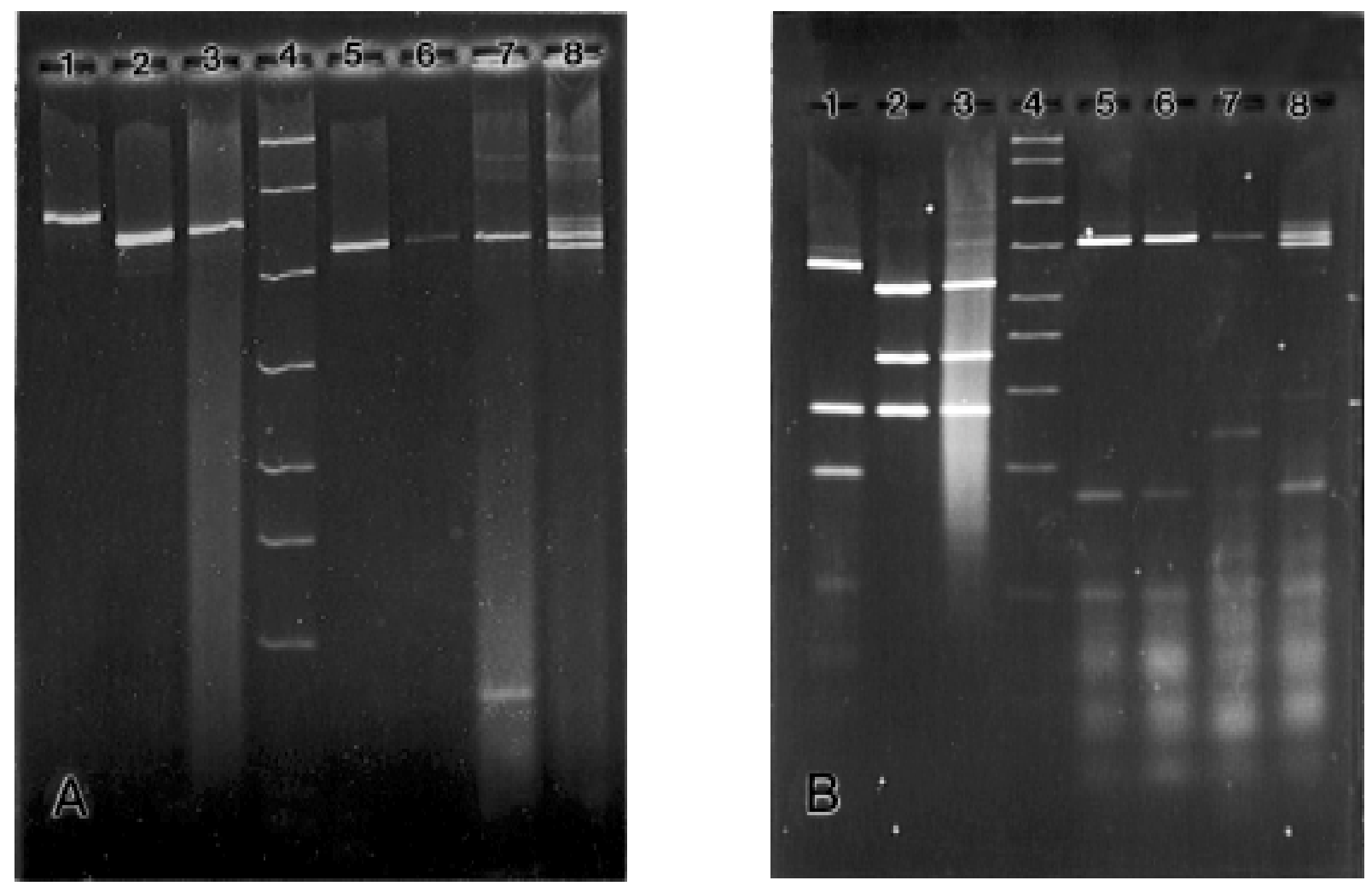

Fig. 2. Electrophoresis of $(\mathbf{A})$ unrestricted PCR products and $(\mathbf{B})$ their corresponding $R s a 1$ digestion products . In both panels, lane $1=P$. sp. 'Torres', lane $2=$ $P$. $\times$ hybrida 'Prime Time Blue', lane 3= $P$. Xhybrida 'Magic White', lane $4=$ standards (2000, 1500, 1000, 700, 500, 400, 300, 200, 100, and 50 bp), lane 5 $=P$. integrifolia sp. depauperata ' 2 ', lane $6=P$. integrifolia sp. depauperata ' 3 ', lane $7=P$. altiplana ' 7 ', and lane $8=P$. altiplana ' 8 '.

'Magic White' were identical and differed from that of either P. altiplana or P. integrifolia ssp. depauperata (Fig. 2; Table 1). Both $P$. integrifolia ssp. depauperata accessions produced a single PCR product of the same length (1220 bp) and two Rsa I restriction fragments of the same length ( 825 and $165 \mathrm{bp})$. Both $P$. altiplana accessions produced two PCR products, one of which was of the same length (1220 bp) as the $P$. integrifolia product. In $P$. altiplana ' 7 ', the other PCR product contained 225 bp and was not digested by Rsa 1, whereas in $P$. altiplana ' 8 ', it contained 1185 bp and was digested by $R s a 1$, producing a 785 bp fragment.

The $R$ sa $I$ restriction data suggest that $P$. altiplana and $P$. integrifolia ssp. depauperata are genetically more similar to each other than to $P$. $\times$ hybrida. This was not unexpected because Petunia altiplana was separated from $P$. integrifolia ssp. depauperata based upon its procumbent leaves and ability to form adventitious roots on its shoots (Ando and Hashimoto, 1993). Both Smith and Downs (1966) and Wijsman (1982) collected $P$. altiplana but did not consider it a separate species distinct from $P$. integrifolia ssp. depauperata.

The unknown species $P$. sp. 'Torres' is morphologically distinct from either $P$. $\times$ hybrida, $P$. altiplana, or $P$. integrifolia $\mathrm{ssp}$. depauperata, with round, glabrous, and succulent leaves. The Rsa 1 banding pattern of $P$. sp. 'Torres' was clearly different from those of either $P$. $\times$ hybrida or $P$. integrifolial $P$. altiplana.

This study shows that variation exists in the intron of the $C h s A$ gene, and that this variation may be species-specific. Of the four different species that were characterized, two could be placed in the same genetic grouping.

\section{Literature Cited}

Ando, T. and G. Hashimoto. 1993. Two new species of Petunia (Solanaceae) from southern Brazil. Bot. J. Linn. Soc. 111:265-280.

Ando, T. and G. Hashimoto. 1994. A new Brazilian species of Petunia (Solanaceae) from the Sierra da Mantiqueira. Brittonia 46:340-343.

Ando, T. and G. Hashimoto. 1995. Petunia guarapuavensis (Solanaceae): A new species from planalto of Parana and Santa Catarina, Brazil. Brittonia 47:328-334.

Ando, T. and G. Hashimoto. 1996. A new Brazilian species of Petunia (Solanaceae) from interior Santa Catarina and Rio do Sul, Brazil. Brittonia 48:217223.

Ando, T. and G. Hashimoto. 1998. Two new species of Petunia (Solanaceae) from southern Rio Grande do Sul, Brazil. Brittonia 50:483-492.

Cerny, T.A., C. Caetano-Anollés, R.N. Trigiano, and T.W. Starman. 1996. Molecular phylogeny and DNA amplification fingerprinting of Petunia taxa. Theor. Appl. Genet. 92:1009-1016.

Fries, R.E. 1911. Die Arten der Gattung Petunia. Kungl. Svenska Vetenskapsakademiens Handlingar 46:172 .

Hooker, W.J. 1831. Salpiglossis integrifolia. Curtis's Bot. Mag. 58:3113.

Jussieu, A.L. 1803. Sur le Petunia, genre nouveau de la famille des plantes solanees. Ann. Museum Nat. d'Hist. 2:214-216.

Kabbaj, A., F. Zeboudj, D. Peltier, A. Tagmount, M. Tersac, H. Dulieu, and A. Berville. 1995. Variation and phylogeny of the ribosomal DNA unit types and 5 S DNA in Petunia. Genetic Res. and Crop Evol. 42:311-325.

Koes, R. E., C.E. Spelt, J.N. Mol, and A.G. Gerats.
1987. The chalcone synthase multigene family of Petunia hybrida (V30): Sequence homology, chromosomal localization and evolutionary aspects. Plant Mol. Biol. 10:375-385.

Koes, R.E., C.E. Spelt, P.J. van Elzen, and J.N. Mol. 1989. Cloning and molecular characterization of the chalcone synthase multigene family of Petunia hybrida. Gene 81:245-257.

Maréchal-Drouard, L. and P. Guillemaut. 1995. A powerful but simple technique to prepare polysaccharide-free DNA quickly and without phenol extraction. Plant Mol. Biol. Rpt. 13:26-30.

Niesbach-Klösgen, U., E. Barzen, J. Bernhardt, W. Rohde, Z. Schwarz-Sommer, H. Reif, U. Wienand, and H. Saedler. 1987. Chalcone synthase genes in plants: A tool to study evolutionary relationships. J. Mol. Evol. 26:213-225.

Schinz, H. and H. Thellung. 1915. Petunia integrifolia (Hooker) Schinz et Thellung comb. nov. Viertelj. Naturforsch. Gesel. Zurich 60:361.

Shepherd, A., S. Anderson, and S. Smith. 1990. Species-specific repeated DNA sequences from Petunia. Plant Sci. 67:57-62.

Sink, K.C. 1984. Petunia. Monogr. Theor. Appl. Gen. 9. Springer-Verlag, Berlin.

Smith, L.B. and R.M. Downs. 1964. Notes on Solanaceae. Phytology 10:439-441, 452-453.

Smith, L.B. and R.M. Downs. 1966. Flora ilustrada Catarinense, Solanaceae. Herbario Barbosa Rodrigues.

Tsukamoto, T., T. Ando, M. Kurata, H. Watanabe, H. Kokubun, G. Hashimoto, and E. Marchesi. 1998. Resurrection of Petunia occidentalis R.E. Fr. inferred from a cross-compatibility study. J. Jpn. Bot. 73:15-21.

Wijsman, H.J.W. 1982. On the interrelationships of certain species of Petunia. I. Notes on the parental species of Petunia hybrida. Acta Bot. Neerl. 31:477-490.

Zeboudj, F., A. Kabbaj, K. Alaoui, D. Peltier, A. Tagmount, C. Raquin, M. Darmency, D. Maizonnier, H. Dulieu, and A. Bervillé. 1994. Variation of ribosomal DNA and inheritance of polymorphisms in six Petunia hybrida lines. Agronomie 14:485-495. 